Dialectologia 15 (2015), 1-33.

ISSN: 2013-2247

Received 22 December 2013.

Accepted 1 March 2014.

\title{
THE ROLE OF DIALECTOLOGY IN ORAL AND WRITTEN EXPRESSION OF EFL STUDENTS: FACULTY PERCEPTIONS OF BRE VERSUS AmE USAGE
}

\author{
Hamad AL-DosARI \\ King Khalid University, Abha, Kingdom of Saudi Arabia \\ hamadaldossary54@yahoo.com
}

\begin{abstract}
Language is a reflection of the dialogic or social phenomenon that sets humans apart from the animals. People interact and share information via cultural transmission from one person to the other. The purpose of this research was to determine the perceptions of English/language arts teachers concerning British English versus American English usage in students' oral and written expression. Using an ethnographic survey research approach, findings indicated that there was a difference between English/language arts teachers' nationality and their perceptions across the three clusters: (a) communicative competence regarding which dialect of English, (b) challenge of teaching Standard English to non-native EFL speakers, and (c) importance of constant correction of nonstandard English usage. In the sample of the study, differences were also detected between English/language arts teachers' years of experience as an educator and their perceptions across the three clusters already cited. As well, there was a difference between English/language arts teachers' academic training in nonstandard English dialects and their perceptions across the same three clusters. Pedagogical implications with regard to teaching which dialect students are required to speak or write in Standard English and whether professional development would help English/language arts teachers and students for teaching and learning Standard English.
\end{abstract}

\section{Keywords}

dialectology, British English (BE) dialect, American English dialect, standard English, students' oral and written expression, communicative competence, non-native English teachers, teacher's attitudes, perceptions 


\section{EL PAPEL DE LA DIALECTOLOGIA EN LA EXPRESIÓN ORAL Y ESCRITA EN ESTUDIANTES DE INGLÉS COMO} LENGUA EXTRANJERA: PERCEPCIONES SOBRE EL INGLÉS BRITÁNICO VERSUS EL INGLÉS AMERICANO

\section{Resumen}

La lengua es un reflejo del fenómeno dialógico o social que diferencia a los humanos de los animales. Las personas interactúan y comparten información a través de la transmisión cultural de una persona a otra. El propósito de esta investigación ha sido determinar las percepciones de profesores de inglés sobre el inglés británico versus el inglés americano en la expresión oral y escrita de los alumnos. Utilizando un cuestionario de investigación etnográfico, los resultados han indicado que hay una diferencia entre la nacionalidad de los profesores de inglés y sus percepciones a través de tres grupos: (a) la competencia comunicativa con respecto a qué dialecto del inglés, (b) el reto de enseñar inglés estándar a estudiantes no nativos de inglés como lengua extranjera, y (c) la importancia de la corrección constante en el uso del inglés no estándar. En la muestra del estudio también se detectaron diferencias entre profesores de inglés con años de experiencia y sus percepciones a través de los tres grupos ya citados. Además, hay una diferencia entre la formación académica de los profesores de inglés en dialectos ingleses no estándar y su percepción a través de los mismos tres grupos. Existen implicaciones pedagógicas respecto a la enseñanza del inglés en estudiantes que están obligados dialectales a hablar o a escribir en inglés estándar y se plantea si el desarrollo profesional ayudaría a los profesores y estudiantes para la enseñanza y el aprendizaje del inglés estándar.

\section{Palabras clave}

dialectología, inglés británico (BE), inglés americano, inglés estándar, expresión oral y escrita de los alumnos, competencia comunicativa, profesores no nativos de inglés, actitudes de los profesores, percepciones

\section{Introduction}

Language diversity exists not only with respect to different distinct languages but also in terms of variation within particular languages. Inherent in these varied modes of interaction are opportune moments for effective communication or sometimes unintended occasions of vast confusion (Reagan 2005). Consequently, EFL educators are faced with greater challenges in meeting the needs of EFL students (Ball 1992; Baugh 2000; Smith 2003).

Ball (1994) recommended that one of the fundamental duties of the education system should be to teach all students to effectively communicate across contexts. In 
order to function well economically, socially, and professionally in mainstream society, an individual needs to be able to correctly and easily use standard English (Pride 1979; Smitherman 2000). However, some researchers agreed that British English, the dialect that the students of EFL in numerous countries learn as the mother language of all Englishes, may enhance access to important social networks in the larger outer circle of the English speaking communities (Craig \& Washington 2002; Delpit 1995).

Over the past five decades, William Labov (1970) emphasized that the fundamental goal of the school was to teach reading and writing of Standard English. In a seminal study of language variation, Labov (1972) provided a sociolinguistic theory of language that underscored the importance of teachers recognizing English dialects, such as American English and its vernaculars (e.g., Black English) or the British dialect and its indigenous vernaculars in the old British colonies (e.g., Australian or Indian Englishes) as variations of standard English. He disputed the claim of Bereiter \& Engelmann (1966), who suggested that nonstandard English was a verbal deprivation. Labov maintained that verbal deprivation theory, also known as linguistic deficit theory, caused detrimental effects to our educational system, thus precluding schools from fully realizing their goal.

\section{Problem of the study}

One of the most challenging issues for English/language arts (ELA) teachers is their responsibility to students who speak nonstandard English (Christenbury 2000). Research enveloping the British English (BE) dialect has focused primarily on the overall structure of British English as the standard language for English teachers and learners around the world, as well as BE speakers' use of the language in social contexts (Baugh 2000; Green 1999; Labov 1972; Mufwene 1999; Smitherman 2000). Although advocates of British English have attempted to promote the authenticity of the language (Green 2002; Labov 1972; Mufwene 1999; Smitherman 2000), others have tried to denounce the dialect as having any legitimacy as the standard language for the English curriculum (Bereiter \& Englemann 1966; Machan \& Scott 1992). 
Despite numerous studies on British English, Green (2002) asserted that limited linguistic studies have focused on the effect of language use of English as a foreign language learners on achievement in language arts. Reagan (2005) explained that any sociolinguistic debate surrounding British versus American English is an educational concern, essentially focused on the most appropriate means of meeting the academic needs of its learners. The study augmented this research base by exploring the perceptions of English/language arts teachers who are confronted daily with the intricacies of the main English dialects and the language's cultural and linguistic differences as perceived by EFL learners and teachers.

\section{Purpose of the study}

The purpose of this research was to determine the perceptions of English/language arts teachers concerning BrE versus AmE usage in EFL students' oral and written expression.

\section{Research questions}

Specific research questions guided the study included the following:

1. Is there a difference between English/language arts teachers' nationality and their perceptions across the three clusters: (a) communicative competence regarding American versus British English, (b) challenge of teaching Standard British English to Saudi EFL learners, and (c) importance of constant correction of nonstandard English usage?

2. Is there a difference between English/language arts teachers' level of education and their perceptions across the three clusters: (a) communicative competence regarding American versus British English, (b) challenge of teaching standard British English to Saudi EFL learners, and (c) importance of constant correction of nonstandard English usage? 
3. Is there a difference between English/language arts teachers' years of experience as an educator and their perceptions across the three clusters: (a) communicative competence regarding American versus British English, (b) challenge of teaching Standard British English to Saudi EFL learners, and (c) importance of constant correction of nonstandard English usage?

4. Is there a difference between English/language arts teachers' academic training in nonstandard English dialects and their perceptions across the three clusters: (a) communicative competence regarding American versus British English, (b) challenge of teaching Standard British English to Saudi EFL learners, and (c) importance of constant correction of nonstandard English usage?

5. What do English/language arts teachers perceive to be the three most frequent American versus British English features evidenced in Saudi EFL students' writing?

\section{Significance of the study}

This study sought to investigate English/language arts teachers' perceptions regarding standard British versus American English usage in students' oral and written expression. This research may be significant in that it revisited the language arts classroom after over 50 years of sociolinguistic discourse. The research was designed to assist EFL educators in better meeting the needs of teaching Standard English to EFL students and other Standard English language learners.

Results from the study may raise the level of awareness of how English/language arts teachers perceive nonstandard English dialects, British or American, to impact students' oral and written expression in the English/language arts classroom. Educators and policymakers may be able to use findings from the study to expand their knowledge base concerning EFL teachers' overall perceptions of American versus English standard and nonstandard usage as well as specific concerns and recommendations with regard to teaching Standard English to EFL learners. 


\section{Methodology}

The researcher employed descriptive research methodology using a survey for examining EFL teachers' Perceptions of American versus British English Dialects Usage. Based on a synthesis of the research literature covering British versus American English usage, the researcher formulated 28 items that examined EFL teachers' perceptions of BrE/AmE English usage in students' oral and written expression. The questionnaire consisted of quantitative questions that included three major sections or clusters collapsible to glean both responses to: (a) demographic information, (b) Likert type questions, and qualitative data gleaned via open-ended comments by the informants in the study.

\section{Review of literature}

Proficiency in oral and written language represents a vital contributor to academic success. One of the goals of the public Saudi educational system with regard to foreign language learning is to train young people to communicate in the standard vernaculars of the major English-speaking communities, the British Isles and the United States of America. In these major English-speaking societies, public school educators encourage students to become literate and develop academic language proficiency (Wong-Fillmore \& Snow 2000). English educators teach students to become adequately trained both orally (speaking and understanding oral speech) and in writing (reading and understanding the written word) (Crawford 2005). However, communicating with other human beings is nearly always challenging; and this task is even more complicated when communicating with people of diverse cultures and languages (Novick 1996; Salend 2001).

In this regard, Reagan (2005) stated that language symbolizes one of the most crucial elements of understanding and responding appropriately to diversity in educational settings. Language performance is closely connected to academic success (Coelho 2004; Delpit 1995; Green 2002; Langdon 1989; Tikunoff 1987). Language is 
important for basic interpersonal communication as well as self-directed language tasks including speaking, reading, and writing (Ball \& Farr 2003; Green 2002; Jax 1988). Ball \& Farr (2003) referred to language as the abstract system underlying the entire speech and writing behavior of a community. Smitherman (2000: 119) stated that language represents the "foundation stone [sic] of education and the medium of instruction in all subjects and disciplines throughout schooling." Yet, not all students enter the educational environment with the same linguistic backgrounds (Ball 1994; Craig \& Washington 2002; Spring 2004). Cazden (1996), Labov (1970), and Smitherman (2000) maintained that in order for teachers to understand their nonstandard English-speaking students and achieve the basic goals of education, they must first gain an understanding of the students' nonstandard language.

Scott \& Machan (1992) maintained that language variation refers to the reality that individual speakers modify their language patterns according to factors such as topic discourse, social relationships, written or spoken communication, and the size and nature of the audience and setting. Research clearly supported the position that variation in language is a natural reflection of cultural and community differences (Ball \& Farr 2003; Labov 1972, 2001; Smitherman \& Baugh 2002).

Ball and Farr (2003) stated that within each community, a variety of language codes and ways of speaking vary according to the levels of different languages, regional and social dialects, registers, and channels of communication.

Linguists maintained that the many varieties of English, or nonstandard English dialects, consisted of logical and highly structured linguistic systems (Bland-Stewart 2005; Green 2002). Likewise, linguists characterized American English with its indigenous vernaculars, such as Black English or the standard North American vernacular, as a distinct dialect with a fully developed, rule-governed structure (Green 2002; Koch, Gross \& Kolts 2001; Labov 1972; Mufwene 1999). However, many Standard English speakers' concomitant views of inferiority often challenged linguists' assertions (Ball 1992; Ball \& Farr 2003; Hoffman 1997; Smitherman 2000). 


\section{History of the development of BrE and AmE}

The English language was first introduced to America by the British colonists, beginning in 1607 in Jamestown, Virginia. By the same token, the language spread to various other regions of the world as a result of British trade and colonization elsewhere and the spread of the former British Empire, which, by 1921, held sway over a population of 470-570 million people, approximately a quarter of the world's population at that time.

Over the past four centuries, the form of the language used in North America and Canada - especially in the United States - and that used in the United Kingdom have diverged in a few minor ways, conducing to the production of the dialects now occasionally referred to as American English (AmE) and British English (BrE). Differences between the two dialects include pronunciation, grammar, vocabulary (lexis), spelling, punctuation, idioms, formatting of dates and numbers, although the differences in written and most spoken grammar structure tend to be much less than those of other aspects of the language in terms of mutual intelligibility. A small number of words have completely different meanings in the two dialects or are even unknown or not used in one of the dialects. One particular contribution towards formalizing these differences came from Noah Webster, who wrote the first American dictionary (published 1828) with the intention of showing that people in the United States spoke a different dialect from Britain, much like a regional accent.

According to Svartvik \& Leech (2006), the most apparent differences between British English and General American can be detected in vocabulary as well as in pronunciation. Approximately 4000 words differ in British English and General American. For instance, in General American one uses the word cell phone, whilst the British English equivalent is mobile phone (Svartvik \& Leech 2006: 153). In terms of the pronunciation of postvocalic $/ r /$ - i.e. the $/ r$ / sound after a vowel in words like store, car and father - there is an additional obvious difference between British English and General American. People who speak British English do not pronounce the $/ \mathrm{r} /$, while people speaking General American do (Modiano 1996: 15). 
This divergence between American English and British English once caused George Bernard Shaw to say that the United States and United Kingdom are "two countries divided by a common language" (Krueger, Stade \& Karbiener 2009: 309); a similar comment is ascribed to Winston Churchill. Similarly, Oscar Wilde wrote, "We have really everything in common with America nowadays, except, of course, the language" (The Canterville Ghost 1888). Henry Sweet incorrectly predicted in 1877 that within a century American English, Australian English and British English would be mutually unintelligible. It may be the case that increased worldwide communication through radio, television, the Internet and globalization has reduced the tendency to regional variation. This can result either in some variations becoming extinct (for instance, the wireless, superseded by the radio) or in the acceptance of wide variations as "perfectly good English" everywhere. Often at the core of the dialect though, the idiosyncrasies remain.

Nevertheless it remains the case that, although spoken American and British English are generally mutually intelligible, there are enough differences to cause occasional misunderstandings or at times embarrassment - for example some words that are quite innocent in one dialect may be considered vulgar in the other.

\section{Teaching English dialects to EFL learners}

The goal of enhancing teacher awareness and understanding of the sociolinguistic and historical roots of English dialectology in colleges that prepare EFL teachers is ultimately to improve the classroom situation for students (Oubre 1997). EFL Educators agreed that in order to improve the academic performance of EFL students, teacher education programs geared towards teaching the English language should ensure that teachers acquire an elevated level of authentic knowledge of American and/or British cultures. These programs should provide a deep understanding of the impact that the British/American culture has on behavior, learning styles, and preferred teaching styles (Berry 2003; Ogbu 2003; Smitherman 2000). 
Some researchers observed in their survey studies that British English was the most general variety of English used when teaching English in Swedish secondary schools (Hurtig 2006). According to the study by Hurtig (2006), teachers thought that British English was more "formal", "correct" and "strict", etcetera than General American. General American was seen as "softer" and "friendlier" than British English. When asking the teachers what their views were on the students' use of British English and General American, the results show that the majority of the teachers thought that it was essential for the students to be familiar with the differences of the two dialects. These findings are seen resounding in relevant research by others (Östlund 2005; Thörnstrand 2008; Trudgill \& Hannah 1994; Rönnerdal \& Johansson 2005)

Ball \& Farr (2003) noted that effective language arts teaching may contribute to positive long-term change if teacher education programs work to combat cultural conflicts. According to Reagan (2005), students in EFL educational institutions who were taught English in a nonstandard dialect continued to be disproportionately misdiagnosed and mislabeled with respect to both cognitive and speech or language problems. Reagan argued that this fact alone constituted a justification for additional teacher preparation with respect to language differences.

Some linguists have cited English/language arts teachers as lacking linguistic competence, frequently mistaking dialect miscues as grammatical errors (Baugh 2000; Delpit 1995; Green 2002). Still, language learning institutions infrequently hired linguists and native speakers to teach EFL where English is a foreign language, and provisioned EFL teacher training programs where they seldom offered linguistics courses geared towards teaching the sociolinguistic and cultural aspects of dialects (Baugh 1998; Cullinan 1974; Matsuda 2006).

Research on students learning English as a second or foreign language has shown that these students frequently achieve at lower levels than native English-speaking children, especially in language-related areas (Jax 1988; Valdez-Pierce 2003).

The typical solution proposed to improve non-native students' proficiency in Standard English has centered on second-language teaching techniques (Mufwene 1999; Smitherman 2000). Wong-Fillmore \& Snow (2000) asserted that in order to effectively teach language proficiency, EFL teachers need to become educational linguists who 
possess a solid knowledge-base and the skills related to language learning and success in school.

Delpit $(1995,1998)$ recommended constructive ways of teaching Standard English to non-native EFL learners. Delpit encouraged such techniques as role-playing, which teaches students that there are many ways to say the same thing, and that certain contexts require particular kinds of linguistic performances. Smitherman (2000) recommended that English/language arts teachers allow EFL students to substitute much written work with activities such as improvisational drama, panel discussions, debates, and short speeches.

LeMoine (2001: 176-177) recommended six principles for teachers of EFL in order to enhance the learners' awareness of dialectal differences between standard and nonstandard English:

1. Building their knowledge and understanding of nonstandard language and the students who speak them.

2. Integrating linguistic knowledge about the different dialects of English, especially British and American English, into instruction.

3. Using second language acquisition methods to support student learning of mainstream school language and literacy.

4. Employing a balanced instructional approach to literacy that incorporates language experience, whole language/access to books, and phonics.

5. Infusing the history and culture of British and American dialects into the curriculum, and

6. Considering the learning styles and strengths of the main dialects of English in designing language curriculum and instruction.

\section{Teacher perceptions and student learning}

For years, teacher attitudes have been recognized as being vital contributors to children's academic success or failure (Labov 1970; Weinstein 2002). Studies of social 
support provided evidence that perceptions of supportive teachers were interconnected with student outcomes in important ways (Valdés 2001; Wentzel 1997).

Valdés (2001) found that attitudinal assessment was important because teachers' attitudes and beliefs about language-minority children played a crucial role in determining the educational outcomes for this student population. Teachers who held negative views toward language-minority students, or who upheld fallacies surrounding their education, often failed to meet the students' academic needs (Valdés 2001; Youngs \& Youngs 2001). Rickford (1999) explained that teachers who lacked knowledge of their students' cultural background imposed detrimental effects on their achievement.

Attitudes toward language consisted of teachers viewing a student's dialect as either a deficit or difference (Baugh 2000; Smitherman \& Baugh 2002). In a study of how Black English and teacher attitudes influenced classrooms, Edwards (1997) found that the teachers failed to support the students' home language and held low expectations for the students' achievement.

Consequently, the students failed to reach their fullest academic potential. Smitherman \& Baugh (2002) argued that negative perceptions of nonstandard speech reflected the belief that vernacular dialects were linguistically inferior to Standard English. Smitherman \& Baugh suggested that harboring low expectations for children was deleterious because it conveyed a sense that the children were inadequate. Researchers of linguistics and language variation attributed pathological views of American English and its vernaculars to the dearth of linguistic understanding among educators (Baugh 2000; Bland-Stewart 2005; Smitherman 2000).

\section{Findings}

As indicated, the participants for this study reflected a purposive sample of $88(\mathrm{~N}=$ 88) EFL instructors in the language skills in a Saudi college of language and translation. The demographic variables for the study included nationality of teachers, highest level of education, and the number of years of experience as an EFL educator, academic 
training in nonstandard English dialects. Frequency tables provided the frequency by percent of occurrences for these independent variables. Tables 1-4 show the frequencies and percentages according to the study participants' demographic variables.

\section{1 Nationality}

Study participants' demographic data included diverse nationalities. However, the non-proportionality of the nationality variable resulted in the collapsing of data into two groups: natives and non-native speakers of English. The nationality demographic variable showed that $88.6 \%$ of the respondents were non-natives, whereas $11.4 \%$ were native speaker teachers of EFL. Table 1 displays the frequencies and percentages for the nationality variable.

\begin{tabular}{|l|l|l|}
\hline Nationality & Frequency & Percent \\
\hline Non-native speakers & 78 & 88.6 \\
\hline Native speakers & 10 & 11.4 \\
\hline Total & 88 & 100.0 \\
\hline
\end{tabular}

Table 1. Frequencies of nationality $(\mathrm{N}=88)$

\section{2 Highest level of education}

The highest level of education variable included two levels: the MA degree and the doctoral degree. The highest level of education variable showed that $15.9 \%$ of respondents obtained MA degree only, whereas $84.1 \%$ of respondents earned doctoral degrees. Table 2 provides the frequencies and percentages for the highest level of education variable.

\begin{tabular}{|l|l|l|}
\hline Highest level of education & Frequency & Percent \\
\hline MA & 14 & 15.9 \\
\hline PhD & 74 & 84.1 \\
\hline Total & 88 & 100.0 \\
\hline
\end{tabular}

Table 2. Frequencies for highest level of education $(\mathrm{N}=88)$ 


\subsection{Years of experience as an EFL educator}

The years of experience as an educator variable consisted of two levels: 1-15years' experience as an educator and 16 or more years' experience as an educator. The years of experience as an educator variable indicated that most respondents (55.7\%) had 16 or more years of experience, whereas the remaining respondents (44.3\%) had 1-15 years' experience. Table 3 shows frequencies and percentages for the years of experience as an educator variable.

\begin{tabular}{|l|l|l|}
\hline Years of experience & Frequency & Percent \\
\hline $1-15$ years & 39 & 44.3 \\
\hline $16+$ years & 49 & 55.7 \\
\hline Total & 88 & 100.0 \\
\hline
\end{tabular}

Table 3. Frequencies for years of experience as an educator $(N=88)$

\section{4 Academic training in nonstandard English dialects}

The academic training in nonstandard English dialects variable included two levels: Yes response and No response. The academic training in nonstandard English dialects variable showed that the majority of the respondents (59.1\%) received no training, whereas $40.9 \%$ of the respondents had received training. Table 4 displays frequencies and percentages for the academic training in nonstandard English dialects variable.

\begin{tabular}{|l|l|l|}
\hline Academic training & Frequency & Percent \\
\hline Training & 36 & 40.9 \\
\hline No training & 52 & 59.1 \\
\hline Total & 88 & 100.0 \\
\hline
\end{tabular}

Table 4. Frequencies for academic training in nonstandard English dialects $(\mathrm{N}=88)$

\section{5 Survey items and cluster analyses}

Cluster analyses revealed the five highest and five lowest survey items of importance to participants, based on their mean responses. The mean responses on the 
Dialectologia 15 (2015), 1-33.

ISSN: 2013-2247

cluster items are shown in Table 5 (highest five) and Table 6 (lowest five). Table 7 supplies the means for each of the dependent variables, or clusters.

\begin{tabular}{|l|l|l|l|}
\hline Survey items & $\mathrm{n}$ & $\mathrm{M}$ & $\mathrm{SD}$ \\
\hline $\begin{array}{l}\text { 8. I am familiar with the differences between BrE and AmE, } \\
\text { standard and nonstandard dialects. }\end{array}$ & 87 & 2.43 & 1.06 \\
\hline $\begin{array}{l}\text { 19. I correct my EFL students' writing each time they use } \\
\text { nonstandard English in their writing pieces. }\end{array}$ & 87 & 2.63 & 1.25 \\
\hline $\begin{array}{l}\text { 13. I clearly understand my EFL students' colloquial syntax in } \\
\text { their everyday conversations. }\end{array}$ & 88 & 2.68 & 1.01 \\
\hline $\begin{array}{l}\text { 12. I am very familiar with AmE that I prefer to teach this } \\
\text { dialect to my EFL students. }\end{array}$ & 88 & 2.98 & 0.91 \\
\hline $\begin{array}{l}\text { 11. I am able to communicate well with my EFL students, no } \\
\text { matter what dialect they use or learn. }\end{array}$ & 87 & 3.07 & 0.97 \\
\hline
\end{tabular}

Table 5. Five highest ranked survey items $(\mathrm{N}=88)$

As shown in the table above, the highest ranked item of importance focused on the teachers' ability to recognise the differences between $\mathrm{BrE}$ and $\mathrm{AmE}$, standard and nonstandard dialects, with which approximately $70 \%$ of the participants agreed. The remaining four highest ranked items of importance (in descending order) included participants' perceptions regarding their: (a) strong rapport with the AmE dialect, (b) comprehension of EFL students' colloquial syntax, (c) constant correction of EFL students' use of nonstandard English in writing, and (d) familiarity with American English dialect.

\begin{tabular}{|l|l|l|l|}
\hline Survey items & $\mathrm{n}$ & $\mathrm{M}$ & $\mathrm{SD}$ \\
\hline $\begin{array}{l}\text { 16. I feel it is necessary to constantly correct EFL students' } \\
\text { use of dialect during class discussions. }\end{array}$ & 88 & 0.95 & 1.02 \\
\hline $\begin{array}{l}\text { 14. I often correct EFL students' use of dialect during } \\
\text { informal discussions. }\end{array}$ & 88 & 1.10 & 1.09 \\
\hline $\begin{array}{l}\text { 18. H is important to correct EFL students each time they } \\
\text { mispronounce a word during reading time. }\end{array}$ & 86 & 1.13 & 1.17 \\
\hline $\begin{array}{l}\text { 22. EFL students should be encouraged to use only Standard } \\
\text { British or American English at and away from the class. }\end{array}$ & 88 & 1.48 & 1.21 \\
\hline $\begin{array}{l}\text { 20. EFL students become frustrated when corrected for } \\
\text { incorrect use of standard English in reading or writing. }\end{array}$ & 86 & 1.71 & 0.99 \\
\hline
\end{tabular}

Table 6. Five lowest ranked survey items $(N=88)$ 
As indicated in the table above, the five lowest ranked areas of importance included participants' perceptions regarding (a) constant correction of EFL students during class discussions, (b) constant correction of EFL students' speech during informal discussions (outside of class), (c) constant correction of EFL students' mispronunciation of words during reading time, (d) reinforcement of only Standard English usage at and away from the class, and (e) EFL students' tendency to become frustrated when corrected for incorrect use of standard English in reading or writing. $70 \%$ of the sample participants disagreed with three survey items in particular (items 14, 16, and 18, respectively): (a) constant correction of EFL students' speech during informal discussions (outside of class), (b) constant correction of EFL students during class discussions, and (c) correction of BE-speaking students each time they mispronounced a word during reading or writing time.

\section{Results in response to the research questions}

The researcher formulated a few research questions which examined English/language arts teachers' perceptions of BrE and AmE usage in students' oral and written expression. The parametric one-way ANOVA, Tukey's HSD Post Hoc, and nonparametric Mann-Whitney U statistics were used for inferential data analyses. Data reduction through measures such as coding and categorization allowed for the analyses of qualitative data to identify emergent themes.

In this study, demographic or independent variables were analysed across the three clusters: (a) communicative competence regarding American versus British English, (b) challenge of teaching Standard British English to Saudi EFL learners, and (c) importance of constant correction of nonstandard English usage. Survey items 8, 11, 12, and 13 comprised cluster one, Communicative Competence Regarding Dialectal Use of English. Cluster two, Challenge of Teaching Standard English to EFL students, included survey items 9, 10,20, and 21. The final cluster, Importance o/Constant Correction of Dialectal English Usage, contained survey items 14, 15, 16, 17, 18, 19, and 22. 
Dialectologia 15 (2015), 1-33.

ISSN: 2013-2247

Research question 1. Is there a difference between English/language arts teachers' nationality and their perceptions across the three clusters: (a) communicative competence regarding American versus British English, (b) challenge of teaching Standard British English to Saudi EFL learners, and (c) importance of constant correction of nonstandard English usage?

The Mann-Whitney $U$ analysis was employed to analyse native versus non-native speakers amongst EFL teachers in the study sample for comparison across each cluster. The Mann-Whitney $U$ test examined central tendency comparisons of the two nationality groups because these groups were non-proportional and violated the normal distribution and homogeneous variance assumptions for the ANOVA. Tables 7-12 provide the mean ranks and Mann-Whitney $U$ results for nationality across each cluster.

The Mann-Whitney $U$ analysis revealed no statistically significant difference $(z=$ $-1.08, p=.28$, two-tailed) in the Communicative Competence Regarding Dialectal Use of English (American versus British English), ranking between the non-native-speakers ( $\mathrm{M}$ rank $=43.46)$ and native speakers $\left(\underline{M}_{\text {rank }}=52.65\right)$ groups. Tables 7-8 provide the mean ranks and Mann-Whitney $U$ results for nationality across each cluster.

\begin{tabular}{|l|l|l|}
\hline Nationality & $\mathrm{n}$ & Mean Rank \\
\hline Nonnatives & 78 & 43.46 \\
\hline natives & 10 & 52.65 \\
\hline
\end{tabular}

Table 7. Mean ranks for nationality by communicative competence regarding dialectal English $(\mathrm{N}=88)$

\begin{tabular}{|l|l|}
\hline Source & Value \\
\hline Mann-Whitney U & 308.50 \\
\hline Wilcoxon W & 3389.50 \\
\hline Z & -1.08 \\
\hline Asymmetrical significance (two-tailed) & .28 \\
\hline
\end{tabular}

Table 8. Mann-Whitney $U$ for nationality by Communicative Competence regarding dialectal use of English $(N=88)$

The Mann-Whitney $U$ analysis depicted no statistically significant difference $(z=$ $-.87, p=.39$, two-tailed) in the Challenge of Teaching Standard English to EFL students ranking between the non-native speakers $(\underline{M}$ rank $=45.34)$ and native speakers $(\underline{M}$ rank $=$ 37.95) groups. Tables 9-10 provide the mean ranks and Mann-Whitney $U$ results for 
non-native and native speakers who responded to the survey according to the Challenge of Teaching Standard English to EFL students cluster.

\begin{tabular}{|l|l|l|}
\hline Nationality & $\mathrm{n}$ & Mean Rank \\
\hline Non-natives & 78 & 45.34 \\
\hline Natives & 10 & 37.95 \\
\hline
\end{tabular}

Table 9. Mean ranks for nationality by Challenge of tTeaching standard English to EFL students $(\mathrm{N}=88)$

\begin{tabular}{|l|l|}
\hline Source & Value \\
\hline Mann-Whitney U & 324.50 \\
\hline Wilcoxon W & 379.50 \\
\hline Z & -.87 \\
\hline Asymmetrical significance (two-tailed) & .39 \\
\hline
\end{tabular}

Table 10. Mann-Whitney $\mathrm{U}$ for nationality by Challenge of Teaching standard English to EFL students $(\mathrm{N}=88)$

The Mann-Whitney $U$ analysis showed no statistically significant difference $(z=$ $-1.28, P=.20$, two-tailed) in the Importance of Constant Correction of nonstandard English Usage cluster, ranking between the non-native speakers $(\underline{M}$ rank $=43.26)$ and native-speakers $(\underline{M}$ rank $=53.20)$ groups. Tables $11-12$ show the mean ranks and MannWhitney $U$ results for non-native and native speakers with respect to the Importance of Constant Correction of Dialectal English Usage cluster.

\begin{tabular}{|l|l|l|}
\hline Nationality & $\mathrm{n}$ & Mean Rank \\
\hline Non-natives & 78 & 43.26 \\
\hline Natives & 10 & 54.20 \\
\hline
\end{tabular}

Table 11. Mean ranks for the importance of Constant Correction of dialectal English usage $(\mathrm{N}=88$ )

\begin{tabular}{|l|l|}
\hline Source & Value \\
\hline Mann-Whitney U & 293.00 \\
\hline Wilcoxon W & 3374.00 \\
\hline Z & -1.28 \\
\hline Asymmetrical significance (two-tailed) & .20 \\
\hline
\end{tabular}

Table 12. Mann-Whitney $\mathrm{U}$ for nationality by importance of Constant Correction of dialectal English usage $(\mathrm{N}=88)$

The Mann-Whitney $U$ analysis indicated no statistically significant difference regarding nationality. However, certain trends emerged from the data. Native speaker respondents $(\mathrm{M}$ rank $=52.65)$ rated the Communicative Competence Regarding 
Dialectal English usage cluster higher than non-native speaker respondents $(\underline{M}$ rank $=$ 43.46). Native-speaker respondents $(\underline{M}$ rank $=54.20)$ also rated the Importance of Constant Correction of Dialectal English Usage cluster higher than native-speaker respondents $\left(\underline{M}_{\text {rank }}=43.26\right)$. These trends suggested that native speaker EFL teachers were more likely than non-native speaker EFL teachers to agree with possessing communicative competence when communicating with EFL English learners. In addition, native speaker respondents were more favourable of constant correction of the English usage of EFL students more than non-native speaker teacher respondents.

Research question 2. Is there a difference between English/language arts teachers' level of education and their perceptions across the three clusters: (a) communicative competence regarding American versus British English, (b) challenge of teaching Standard British English to Saudi EFL learners, and (c) importance of constant correction of nonstandard English usage?

The Mann-Whitney $U$ analysis used MA and PhD groups for comparison across each cluster. The Mann-Whitney $U$ test examined central tendency comparisons of the two levels of education groups because these groups were non-proportional and violated the normal distribution and homogeneous variance assumptions for the ANOVA. Tables 13-18 show the mean ranks and Mann-Whitney $U$ test results for highest level of education of respondents with regard to each cluster.

The Mann-Whitney $U$ analysis showed no statistically significant difference $(z=-$ $.75, p=.45$, two-tailed) in the Communicative Competence Regarding Dialectal Use of English (American versus British English), ranking between the $M A$ group ( $\mathrm{M}$ rank $=$ 39.82) and Doctoral $(\underline{M}$ rank $=45.39)$ group. Tables $13-14$ show the mean ranks and Mann-Whitney $U$ results for $\mathrm{MA}$ and $\mathrm{PhD}$ groups with respect to the Communicative Competence Regarding Dialectal Use of English cluster.

\begin{tabular}{|l|l|l|}
\hline Education & $\mathrm{n}$ & Mean Rank \\
\hline PhD & 14 & 45.39 \\
\hline MA & 74 & 39.82 \\
\hline
\end{tabular}

Table 13. Mean ranks for highest level of education by Communicative Competence regarding dialectal English $(\mathrm{N}=88)$ 


\begin{tabular}{|l|l|}
\hline Source & Value \\
\hline Mann-Whitney U & 452.50 \\
\hline Wilcoxon W & 557.50 \\
\hline Z & -.75 \\
\hline Asymmetrical significance (two-tailed) & .45 \\
\hline
\end{tabular}

Table 14. Mann-Whitney $U$ for highest level of education by Communicative Competence regarding dialectal use of English ( $N=88)$

The Mann-Whitney $U$ analysis depicted no statistically significant difference $(z=$ $-1.00, p=.32$, two-tailed) in the Challenge of Teaching Standard English to Dialectal English Usage, ranking between the bachelor's $(\underline{M}$ rank $=50.71)$ and graduate $(\underline{M}$ rank $=$ 43.32) groups. Tables $15-16$ provide the mean ranks and Mann-Whitney $U$ results for MA and PhD groups with respect to the Challenge of Teaching Standard English to EFL Learners cluster.

\begin{tabular}{|l|l|l|}
\hline Education & $\mathrm{n}$ & Mean Rank \\
\hline PhD & 14 & 50.71 \\
\hline MA & 74 & 43.32 \\
\hline
\end{tabular}

Table 15. Mean ranks for highest level of education by Challenge of Teaching standard English to EFL learners $(\mathrm{N}=88)$

\begin{tabular}{|l|l|}
\hline Source & Value \\
\hline Mann-Whitney U & 431.00 \\
\hline Wilcoxon W & 3206.00 \\
\hline Z & -1.00 \\
\hline Asymmetrical significance (two-tailed) & .32 \\
\hline
\end{tabular}

Table 16. Mann-Whitney $U$ for highest level of education by Challenge of Teaching standard English to EFL learners $(N=88)$

The Mann-Whitney $U$ analysis displayed no statistically significant difference $(z=$ $-1.42, p=.16$, two-tailed) in the Importance of Constant Correction of English Usage ranking between the $\mathrm{MA}(\underline{\mathrm{M}}$ rank $=53.39)$ and $\mathrm{PhD}\left(\underline{\mathrm{M}}_{\text {rank }}=42.82\right)$ groups. Tables 17-18 show the mean ranks and Mann-Whitney $U$ results for MA and PhD groups for the Importance of Constant Correction of English Usage cluster. 
Dialectologia 15 (2015), 1-33.

ISSN: 2013-2247

\begin{tabular}{|l|l|l|}
\hline Education & $\mathrm{n}$ & Mean Rank \\
\hline $\mathrm{PhD}$ & 14 & 53.39 \\
\hline $\mathrm{MA}$ & 74 & 42.82 \\
\hline
\end{tabular}

Table 17. Mean ranks for highest level of education by importance of Constant Correction of English usage $(\mathrm{N}=88)$

\begin{tabular}{|l|l|}
\hline Source & Value \\
\hline Mann-Whitney U & 393.50 \\
\hline Wilcoxon W & 3168.50 \\
\hline Z & -1.42 \\
\hline Asymmetrical significance (two-tailed) & .16 \\
\hline Table 18. Mann-Whitney U for highest level of education by importance of Constant Correction of English \\
usage ( $\mathrm{N}=88$ )
\end{tabular}

Although the Mann-Whitney $U$ results indicated no statistical significance regarding highest level of education, certain trends emerged from the data. MA group $\left(\underline{M}_{\text {rank }}=50.71\right)$ reflected a higher mean rank than the PhD group $(\underline{M}$ rank $=53.39)$ on the cluster, Challenge of Teaching Standard English to EFL Learners. The MA group of teachers $(\underline{M}$ rank $=53.39)$ also showed a higher mean rank than the PhD group $(\underline{M}$ rank $=$ 42.82) on the Importance of Constant Correction of Dialectal English Usage cluster. These trends suggested that EFL teachers possessing only the MA degree tended to agree at a higher rate than teachers with graduate degrees that teaching Standard English to EFL students is a challenging task. In addition, teachers possessing only the MA degree were more likely than teachers with PhD degrees to favour constant correction of dialectal English usage.

Research question 3. Is there a difference between English/language arts teachers' years of experience as an educator and their perceptions across the three clusters: (a) communicative competence regarding American versus British English, (b) challenge of teaching Standard British English to Saudi EFL learners, and (c) importance of constant correction of nonstandard English usage?

One-way analysis of variance (ANOVA) tested the difference in sample means for participants' years of experience as an EFL educator. Results from the ANOVA analysis showed no statistical significance in the sample means for years of experience as an EFL educator on the cluster, Communicative Competence Regarding Dialectal English, F (2, 
$87)=1.30, p=.26$. Tables $19-20$ display the ANOVA results for teacher's years of experience as an EFL educator across the Communicative Competence Regarding Dialectal English cluster.

\begin{tabular}{|l|l|l|l|}
\hline Teaching experience & $\mathrm{n}$ & $\mathrm{M}$ & SD \\
\hline $1-15$ yrs. & 39 & 2.68 & .80 \\
\hline $16+$ yrs. & 49 & 2.87 & .80 \\
\hline Total & 88 & 2.79 & .80 \\
\hline
\end{tabular}

Table 19. Means and standard deviations for years of experience as an EFL educator by Communicative Competence regarding dialectal English usage $(\mathrm{N}=88)$

\begin{tabular}{|l|l|l|l|l|l|}
\hline Source & SS & $d f$ & MS & $F$ & $P$ \\
\hline Between groups & .82 & 1 & .82 & 1.30 & .26 \\
\hline Within groups & 54.32 & 86 & .63 & & \\
\hline Total & 55.14 & 87 & & & \\
\hline
\end{tabular}

Table 20. Analysis of variance for years of experience as an EFL educator by Communicative Competence regarding dialectal English usage $(\mathrm{N}=88)$

Results from the ANOVA analysis exhibited no statistical significance in the sample means for years of experience as an educator on the cluster, Challenge of Teaching Standard English to EFL Learners, $F(1,87)=1.56, p=.21$. Tables 21-22 show the ANOVA results for teacher's years of experience as an EFL educator across the Challenge of Teaching Standard English to EFL Learners cluster.

\begin{tabular}{|l|l|l|l|}
\hline Teaching Experience & $\mathrm{n}$ & $\mathrm{M}$ & $\mathrm{SD}$ \\
\hline $1-15$ yrs. & 39 & 2.02 & .77 \\
\hline $16+$ yrs. & 49 & 1.82 & .76 \\
\hline Total & 88 & 1.91 & .77 \\
\hline
\end{tabular}

Table 21. Means and standard deviations for years of experience as an EFL educator by Challenge of Teaching standard English to EFL learners $(\mathrm{N}=88)$

\begin{tabular}{|l|l|l|l|l|l|}
\hline Source & SS & $d f$ & MS & $F$ & $P$ \\
\hline Between groups & .91 & 1 & .91 & 1.30 & .21 \\
\hline Within groups & 50.19 & 86 & .58 & 1.56 & \\
\hline Total & 51.10 & 87 & & & \\
\hline
\end{tabular}

Table 22. Analysis of variance for years of experience as an EFL educator by Challenge of Teaching standard English to EFL learners ( $N=88$ ) 
Results from the ANOVA analysis showed no statistical significance in the sample means for years of experience on the cluster, Importance of Constant Correction of English Usage, $F(1,87)=1.60, p=.21$. Tables $23-24$ show the ANOVA results for teacher's years of experience as an EFL educator across the Importance of Constant Correction of English Usage cluster.

\begin{tabular}{|l|l|l|l|}
\hline Teaching Experience & $\mathrm{n}$ & $\mathrm{M}$ & SD \\
\hline $1-15$ yrs. & 39 & 1.75 & .95 \\
\hline $16+$ yrs. & 49 & 1.52 & .77 \\
\hline Total & 88 & 1.62 & .86 \\
\hline
\end{tabular}

Table 23. Means and standard deviations for the importance of Constant Correction of English usage cluster $(\mathrm{N}=88)$

\begin{tabular}{|l|l|l|l|l|l|}
\hline Source & SS & $d f$ & $M S$ & $F$ & $P$ \\
\hline Between groups & 1.17 & 1 & 1.17 & 1.30 & .21 \\
\hline Within groups & 62.70 & 86 & .73 & 1.60 & \\
\hline Total & 63.86 & 87 & & & \\
\hline
\end{tabular}

Although the one-way ANOVA results indicated no statistically significant difference in respondents' means for the years of experience as an EFL educator variable, specific trends emerged from the data. EFL teachers with 1-15 years' experience had a higher mean $(M=2.02)$ than $E F L$ teachers with 16 or more years' experience $(M=1.82)$ on the Challenge of Teaching Standard English to EFL Learners cluster. This finding suggested that EFL teachers with the least experience were more apt to agree that teaching Standard English to EFL learners is a challenging task. EFL teachers with 1-15 years' experience also had a higher mean $(M=1.75)$ than $E F L$ teachers with 16 or more years' experience $(M=1.52)$ on the Importance of Constant Correction of Dialectal English Usage cluster. This finding suggested that EFL teachers with the least experience were more inclined to favour constant correction of English usage.

Research question 4. Is there a difference between English/language arts teachers' academic training in nonstandard English dialects and their perceptions across the three clusters: (a) communicative competence regarding dialectal English usage (American 
versus British English), (b) challenge of teaching Standard British English to Saudi EFL learners, and (c) importance of constant correction of nonstandard English usage?

One-way analysis of variance (ANOVA) tested the difference in sample means for academic training in nonstandard English dialects. Tables 25-26 show the means, standard deviations, and ANOVA results for academic training in nonstandard English dialects with respect to each cluster.

Results from the ANOVA analysis displayed no statistical significance in the sample means for teachers' academic training in nonstandard English dialects on the cluster, Communicative Competence Regarding Dialectal English, $F(1,87)=.14, p=.71$. Tables 25-26 provide the ANOVA results for teachers' academic training in nonstandard English dialects on the Communicative Competence Regarding Dialectal English cluster.

\begin{tabular}{|l|l|l|l|}
\hline Academic training & $\mathrm{n}$ & $\mathrm{M}$ & $\mathrm{SD}$ \\
\hline Training & 36 & 2.83 & .89 \\
\hline No training & 52 & 2.76 & .73 \\
\hline Total & 88 & 2.79 & .80 \\
\hline
\end{tabular}

Table 25. Means and standard deviations for academic training in nonstandard English dialects by Communicative Competence regarding dialectal English usage $(\mathrm{N}=88)$

\begin{tabular}{|l|l|l|l|l|l|}
\hline Source & SS & $d f$ & $M S$ & $F$ & $P$ \\
\hline Between groups & .09 & 1 & .09 & .14 & .71 \\
\hline Within groups & 55.05 & 86 & .64 & & \\
\hline Total & 55.14 & 87 & & & \\
\hline
\end{tabular}

Table 26. Analysis of variance for academic training in nonstandard English dialects by Communicative Competence regarding dialectal English usage $(\mathrm{N}=88)$

Results from the ANOVA analysis exhibited no statistical significance in the sample means for teachers' academic training in nonstandard English dialects on the cluster, Challenge of Teaching Standard English to EFL Learners, $F(1,87)=.88, p=.35$. Tables 27-28 display the ANOVA results for teachers' academic training in nonstandard English dialects relative to the Challenge of Teaching Standard English to EFL Learners cluster. 
Dialectologia 15 (2015), 1-33.

ISSN: 2013-2247

\begin{tabular}{|l|l|l|l|}
\hline Academic training & $\mathrm{n}$ & $\mathrm{M}$ & $\mathrm{SD}$ \\
\hline Training & 36 & 1.81 & .80 \\
\hline No training & 52 & 1.97 & .74 \\
\hline Total & 88 & 1.91 & .77 \\
\hline
\end{tabular}

Table 27. Means and standard deviations for academic training in nonstandard English dialects by Challenge of Teaching Standard English to EFL learners ( $N=88)$

\begin{tabular}{|l|l|l|l|l|l|}
\hline Source & SS & $d f$ & $M S$ & $F$ & $P$ \\
\hline Between groups & .52 & 1 & .52 & .88 & .35 \\
\hline Within groups & 50.58 & 86 & .59 & & \\
\hline Total & 51.10 & 87 & & & \\
\hline
\end{tabular}

Table 28. Analysis of variance for academic training in nonstandard English dialects by Challenge of Teaching standard English to EFL learners $(\mathrm{N}=88)$

Results from the ANOVA analysis presented no statistical significance in the sample means for teachers' academic training in nonstandard English dialects on the cluster, Importance of Constant Correction of English Usage, $F(I, 87)=.94, p=.34$. Tables 29-30 show the ANOVA results for teachers' academic training in nonstandard English dialects relative to the Importance of Constant Correction of English Usage cluster.

\begin{tabular}{|l|l|l|l|}
\hline Academic training & $\mathrm{n}$ & $\mathrm{M}$ & $\mathrm{SD}$ \\
\hline Training & 36 & 1.73 & .83 \\
\hline No training & 52 & 1.55 & .88 \\
\hline Total & 88 & 1.62 & .86 \\
\hline
\end{tabular}

Table 29. Means and standard deviations for academic training in nonstandard English dialects by importance of Constant Correction of English usage $(N=88)$

\begin{tabular}{|l|l|l|l|l|l|}
\hline Source & SS & $d f$ & $M S$ & $F$ & $P$ \\
\hline $\begin{array}{l}\text { Between } \\
\text { groups }\end{array}$ & .69 & 1 & .69 & .94 & .34 \\
\hline Within groups & 63.17 & 86 & .74 & & \\
\hline Total & 63.86 & 87 & & & \\
\hline
\end{tabular}

Table 30. Analysis of variance for academic training in nonstandard English dialects by importance of Constant Correction of English usage $(\mathrm{N}=88)$

Although the one-way ANOVA results showed no statistically significant differences in respondents' means for the academic training in nonstandard English 
dialects variable, trends emerged from the data. EFL teachers with academic training in nonstandard English dialects had a higher mean $(M=2.83)$ than EFL teachers with no academic training $(M=2.76)$, on the Communicative Competence Regarding Dialectal English cluster. This finding suggested that EFL teachers who had been trained in nonstandard English dialects were more inclined to agree that they possessed communicative competence with regard to communicating with EFL learners.

EFL teachers with academic training in nonstandard English dialects as well as EFL teachers with no academic training tended to disagree with constant correction of Dialectal English usage. However, EFL teachers with training $(M=1.73)$ rated the Constant Correction of English Usage cluster higher than EFL teachers with no training $(M=1.55)$. This result suggested that EFL teachers who had been trained in nonstandard English dialects were slightly more likely than EFL teachers with no training to favour constant correction of dialectal English usage.

Research question 5. What do English/language arts teachers perceive to be the three most frequent American versus British English features evidenced in Saudi EFL students' writing?

Survey participants offered specific comments relating to their concerns about teaching Standard English to BE-speaking students. Three major themes emerged from the data.

The most cited concern involved the need for EFL learners to recognize the relevance of having a sense of audience and purpose in spoken and written discourse in order to become successful in using English in the mainstream society where the language is used for its communicative purposes. One teacher expressed this need in his comment as follows, "I tried to impress upon all my students the need for a sense of audience... Correct use of Standard English is necessary in college applications, job interviews, conversations."

Another respondent noted, "A concern I have is that EFL students are not given equal consideration and training as to when to shift language register for purpose and audience."

A different participant aptly observed: "I stress the importance of considering the audience when speaking and writing. I encourage my EFL students to speak in the best 
way to communicate with a particular audience. With friends at the mall - speak informally. At a job interview - speak formally. They need to understand that language is a tool that we manipulate for specific purposes."

Another teacher commented: "My concern is for their success, or lack of success, in the workforce due to their need to learn standard English for formal language use situations in their jobs when they graduate."

Other responses included concerns with EFL students being "expected to have control of Standard English" and having "code-switching" abilities, or being "able to move comfortably back and forth between Standard English and nonstandard English, whether the dialect is British or American".

A second concern that surfaced was the EFL teachers' frustration resulting from their learners' inability to recognize the need for dialectal English instruction. One respondent noted that the EFL learners "don't understand why it matters." Some teachers revealed the frustration that results from trying to persuade EFL to use Standard British English where American English is more prevalent in Saudi Arabia. One participant explained that "as a white teacher, it is difficult to persuade EFL students to use standard British English in formal writing/settings because one dialect is superior or older than the other". A teacher emphasized that "EF students often write the way they talk. This frustrates me at times because when we go over or review their writing, they can often pick out their mistakes, but not until they re-read it several times."

Other respondents were concerned with the idea that "they speak informal, nonstandard American English at home and with friends so they feel it is acceptable everywhere." One teacher summarized this concern: "In conversational English, outside the classroom, the use of informal American English continues to be reinforced in their home and peer groups. I try to emphasize that the written aspect of language must be 'standard' and that they should work hard on the oral use of language as well, since many first impressions are made from someone's speech. It is frustrating...".

Finally, EFL teachers expressed the need to find a balance between enforcing Standard English and being linguistically responsive to diverse language needs of EFL learners. Another teacher noted that a "concern when teaching EFL students, or other 
ESL students, is how to find the balance between their own spoken language and standard English in writing."

\section{Discussion and conclusion}

Participants in the present study had approximately two decades of teaching experience and no training in nonstandard English dialects. EFL teachers tended to disagree with constant correction of English usage by dialect, although younger, less experienced teachers were more compelled to favour constant correction of the dialect to be the standard British English. Participants expressed a desire to find a balance between enforcing Standard British English and maintaining cultural sensitivity and the language needs of EFL learners who pick up the language mostly via American movies. They indicated a need for EFL teachers to receive professional development training in English dialect variations and cultural awareness in order to more effectively teach Standard English, be it British or American, to non-native EFL students.

In addition, the majority of these teachers possessed doctoral degrees and approximately two decades of teaching experience. Results showed that these teachers lacked training in nonstandard English dialects, however, supporting the assertion of Baugh (2000), Matsuda (2006) and Smitherman (2000) concerning the dearth of linguistic training among teachers.

Based on the findings of the present study, EFL teachers should value students, remaining patient and culturally as well as linguistically sensitive when teaching Standard English. In addition, they should correct linguistic differences gradually and with diplomacy. These findings supported Delpit (1998), Coelho (2004), and Smitherman (2000) assertion that teachers should use constructive methods for teaching Standard English to EFL learners, avoiding humiliating situations resulting from constant correction. 


\section{Implications for educational practice}

1. A need seems to exist for English/language arts EFL teachers to familiarize themselves with the variations among the diverse English dialects, mainly American and British standard dialects in order to effectively communicate with and teach standard English to non-native EFL learners.

2. Universities and graduate teacher preparation programs may need to provide more linguistic courses in nonstandard English dialects to adequately prepare prospective teachers of English in EFL settings.

3. English departments may benefit by assessing the extent to which EFL teachers have been trained in nonstandard English dialects and providing opportunities for professional development training in this area.

4. The findings from this study suggested that constant correction of standard English dialects inhibits student learning. In addition to the research literature which supports these findings, statistical significance surfaced between younger and older teachers regarding their tendency to disagree with constant correction of standard English usage. Therefore, it is recommended that teachers avoid constant correction of dialectal English usage altogether.

5. Based on the research findings, EFL teachers should particularly focus on effective means of teaching correct uses of oral and written English according to both $\mathrm{BrE}$ and AmE dialects by employing instructional methods such as contrastive analysis and code switching techniques in which students are able to compare correct uses of Standard English and its correct dialectal English features both in BrE and AmE dialects (Ball \& Farr 2003; Green 2002; Smitherman 2000).

6. Based on the findings and research literature, it is recommended that future teacher preparation programs target research-based practices that will assist beginning English/language arts teachers in teaching dialectal variations in standard language use. These programs may benefit by specifically focusing on achieving a balanced approach to language arts instruction through cultural sensitivity and linguistic competence. 


\section{References}

BALL, A. (1992) "Cultural preference and the expository writing of African American adolescents", Written Communication, 9(4), 501-532.

BALL, A. (1994) "Investigating language, learning, and linguistic competence of African-American children: Torrey revisited", Linguistics and Education, 7(1), 23-46.

BALL, A. \& M. FARR (2003) "Language varieties, culture, and teaching the English language arts", in J. Flood, D. Lapp, J. R. Squire \& J. M. Jensen (eds.), Handbook of research on teaching the English language arts, Mahwah, NJ: Erlbaum, 435-445.

BAUgh, J. (2000) Beyond Ebonies, New York: Oxford University Press.

Bereiter, C. \& S. ENGLEMANN (1966) Teaching disadvantaged children in the preschool, Englewood Cliffs, NJ: Prentice-Hall.

BLAND-STEWART, L. M (2005) "Research to practice: Tools for non-biased assessment", Paper to be presented to the American Speech Language and Hearing Association Annual Meeting, San Diego, CA.

BERRY, R. (2003) “Mathematics standards, cultural styles, and learning preferences: The plight and the promise of African American students", Clearing House, 76(5), 244-249.

CAZDEN, C. (1996) "How knowledge about language helps the classroom teacher-or does it?", in B. Power \& R. Hubbard (eds.), Language Development, Englewood Cliffs, NJ: Prentice Hall, 87-100.

CHRISTENBURY, L. (2000) $)^{2}$ Making the journey: Being and becoming a teacher of English language arts, Portsmouth, VA: Boynton/Cook Publishers.

COELHO, E. (2004) Adding English: A guide to teaching in multilingual classrooms, Toronto, Canada: Pippin Publishing.

CRAWFORD, J. (2005) Educating English Language Learners, Los Angeles: Bilingual Education Services.

CRAIG, H. \& J. WASHINGTON (2002) “Oral language expectations for African American preschoolers and kindergartners", American Journal of Speech-Language Pathology, 11, 59-70.

CULLINAN, B. (ed.) (1974) Black dialects and reading, Urbana, IL: NCTE.

DELPIT, L. (1995) Other people's children: Cultural conflicts in the classroom, New York: New Press.

EdWARDS, A.D. (1997) "Oral Language, Culture and Class", in Davies, B. \& D. Corson (eds.), Encyclopedia of Language and Education, Vol. 13, Dordrecht, Netherlands: Kluwer Publishers, 65-73. 
Dialectologia 15 (2015), 1-33.

ISSN: 2013-2247

FillmoRE, L. W. \& SNOW, C. E. (2000) "What teachers need to know about language", Available: <http://www.cal.org/ericcll/teachers/teachers.pdf $>$.

GREEN, E. (1999) A marshland of ethno-linguistic boundaries: Conflicting past and present tense be paradigms in coastal Carolina speech, Master's thesis, North Carolina State University, Raleigh.

Green, L. (2002) “A descriptive study of African American English: Research in linguistics and education", Qualitative Studies in Education, 15(6), 673-690.

HOFFMAN, M. (1997) “Ebonics: The third incarnation of a thirty-three year old controversy about Black English in the United States", Links \& Letters, 5, 75-78.

HURTIG, M. (2006) Varieties of English in the Swedish Classroom, 'Läroplan för de frivilliga skolformerna 94'.

JAX, V. (1988) "Understanding school language proficiency through the assessment of story construction", in A. A. Ortiz \& B. A. Ramirez (Eds.), Schools and the culturally diverse exceptional student: Promising practices and future directions, Reston, V A: The Council for Exceptional Children, 45-50.

KOCH, L., A. GROSS \& R. KOLTS (2001) “Attitudes toward Black English and Code-switching”, Journal of Black Psychology, 27, 29-42.

KRUEger, C., G. StAdeM \& K. KARBIEner (2009) Encyclopedia of British Writers: 19th and 20th Centuries, Book Builders LLC Infobase Publishing.

LABOV, W. (1970) The study of nonstandard English, Champaign, IL: National Council of Teachers of English.

LABOV, W. (1972) Sociolinguistic Patterns, Philadelphia: University of Pennsylvania Press.

LABOV, W. (2001) Principles of linguistic change, Vol. 2, Oxford: Blackwell.

LANGDON, H. (1989) "Language disorder or difference? Assessing the language skills of Hispanic students", Exceptional Children, 56, 160-167.

LEMOINE, J. F. (2001) "Situations d'utilisation anticipées du produit et diversité des attentes du consommateur: le cas de l'automobile", Consommations et Sociétés, 1, 47-58.

MACHAN, T. \& C. Scott (eds.) (1992) English in its social contexts: Essays in historical sociolinguistics, Oxford, England: Oxford University Press.

MATSUDA, P. K. 2006 (2006) "The myth of linguistic homogeneity in U.S. college composition", College English, 68(6), 637-651.

Modiano, M. (1996) A Mid-Atlantic Handbook: American and British English, Lund: Studentlitteratur. 
MufWENE, S. (1999) "Ebonies and Standard English in the classroom: Some issues", in I. Alatis \& A. Tan (eds.), Georgetown University Round Table on Languages and Linguistics, Washington, DC: Georgetown University Press, 253-261.

Novick, R. (1996) Developmentally appropriate and culturally responsive education: Theory in practice. Programme Report, The Northwest Regional Educational Laboratory, Portland, OR.

OGBU, J. (2003) Black American students in an affluent suburb: A study of academic disengagement, Mahwah, NJ: Erlbaum.

ÖstLUND, F. (2005) British vs American English - Pronunciation in the EFL Classroom, Retrieved online August, $21^{\text {st }}, 2012$, from

<http://www.essays.se/about/features+of+the+English+language/?startrecord=21>.

OUBRE, A. (1997) “Black English vernacular (Ebonies) and educability: A cross-cultural perspective on language, cognition, and schooling", Retrieved online, $21^{\text {st }}$ August, 2012, from $<$ Cognition and. Schooling, online http:// www.phaelos.com/oubre.html>.

PRIDE, J. (ed.) (1979) Sociolinguistic aspects of language learning and teaching, Oxford, England: Oxford University Press.

Reagan, T. (2005) "Accents and dialects: Ebonies and beyond", in T. Osborne. (ed.), Language and cultural diversity in Us. schools, Westport, CT: Praeger, 39-50.

RICKFORD, A. (1999) I can fly, Lanham MD: University Press of America.

RÖNNERDAL, G. \& S. JOHANSSON (2005) Introducing English Pronunciation: Advice for Teachers and Learners. American version. Third revised Edition, Lund: Studentlitteratur.

SALEND, S. (2001) $)^{4}$ Creating inclusive classrooms: Effective and reflective practices, Columbus, $\mathrm{OH}$ : Merrill/Prentice Hall.

SCOTT \& MACHAN (1992) p. 7 Scott, T. and Machan, C. (1992).English in Its Social Contexts: Essays in Historical Sociolinguistics. Oxford University Press, New York, New York.

SMITH, D. (2003) ${ }^{4}$ Introduction to special education: Teaching in an age of opportunity, Boston: Allyn \& Bacon.

SMitherman, G. (2000) Talkin that talk: Language culture and education in African America, New York: Routledge.

SMitherman, G. \& J. BAUgh (2002) "The shot heard from Ann Arbor: Language research and public policy in African America", Howard Journal of Communications, 13 (1): 5-24

SPRING, J. (2002) ${ }^{10}$ American education, New York: McGraw-Hill Companies, Inc.

SVARTVIK, J. \& G. LEECH (2006) English. One tongue, many voices, Basingstoke: Palgrave Macmillan. 
Dialectologia 15 (2015), 1-33.

ISSN: 2013-2247

THÖRNSTRAND, Å. (2008) "British or American English? A survey of some upper secondary schools", Engelska C terminsuppsats, Karlstads universitet, Karlstad. Retrieved online August, 21st , 2012, from https://docs.google.com/

TIKUNOFF, W. (1987) "Mediation of instruction to obtain equality of effectiveness", in S. Fradd \& W. Tikunoff (Eds.), Bilingual education and bilingual special education: A guide for administrators, Boston: Little, Brown and Company, 99-132.

TRUDGILL, P. \& J. HANNAH (1994) $)^{3}$ International English. A guide to the varieties of Standard English, London: Edward Arnold.

VALDÉS, G. (2001) Learning and not learning English: Latino students in American Schools, New York: Teachers College Press.

VAldez-PIERCE, L. 2003 Assessing English language learners, Washington, DC: National Education Association.

WEINSTEIN, R. S. (2002) Reaching higher: the power of expectations in schooling, Cambridge, MA: Harvard University Press.

WENTZEL, K. R. (1997) "Student motivation in middle school: The role of perceived pedagogical caring", Journal of Educational Psychology, 89, 411-419.

WILDE, O. (1888) The Oscar Wilde Collection. Retrieved online from $<$ http://wilde.astorialand.com/>

WONG-FILLMORE, L. \& C. E. SNOW (2000) What teachers need to know about language (Paper prepared for the Center for Applied Linguistics), Washington, DC: U.S. Department of Education, Office of Educational Research and Improvement.

YounGS, C. \& G. YOUNGS (2001) “Predictors of mainstream teachers' attitudes toward ESL students", TESOL Quarterly, 35, (1), 97-118 